Conclusions DM supplement to MM supports growth in VLBWI without adversely affecting Low $\mathrm{Na}$ or NumNa.

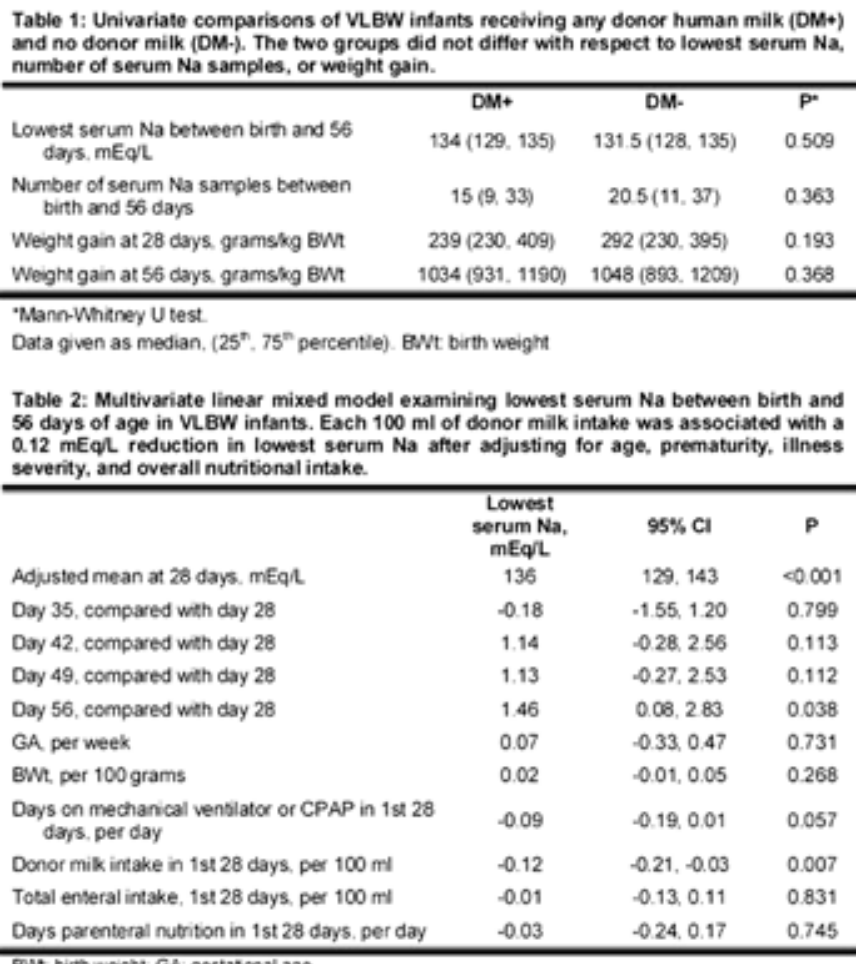

\section{EFFECT OF FORTIFIERS AND ADDITIONAL PROTEIN ON THE OSMOLARITY OF HUMAN MILK- IS IT SAFE FOR THE PREMATURE INFANT?}

doi:10.1136/archdischild-2012-302724.1398

N Haiden, A Kreissl, V Zwiauer, A Repa, C Binder, N Haninger, A Berger. Department of Pediatrics, Medical University of Vienna, Vienna, Austria

Background and Aims A new additional protein supplement (Aptamil Protein $+\circledR /$ Milupa) was developed to meet special protein requirements of infants with a birthweight below 1000g (4.0-4.5 g protein $/ \mathrm{kg} /$ day). So far it was unknown, how this new protein supplement influences osmolarity, which is known to be a risk factor for necrotising enterocolitis (NEC). The aim of this study was to evaluate the effects of fortification on the osmolarity of human milk (HM).

Methods Osmolarity of breast milk was measured in native HM, in HM+ HMF (human milk fortifier; Aptamil FMS 4.3\%®, Milupa) and in $\mathrm{HM}+\mathrm{HMF}+$ Protein+ gaining in $0.5 \mathrm{~g}$ steps up to $4 \mathrm{~g}$. Measurements were performed immediately after adding on fortifier and/or protein and after 24 hours. In addition, changes in osmolarity after adding therapeutic additives like iron (Ferrum Hausmann ${ }^{\circledR}$, Vifor), multivitamine supplement (Protovit ${ }^{\circledR}$, Bayer) and calciumphosphorus capsules were measured.

Results Osmolarity of native human milk ( $\mathrm{n}=84$ ) was $297 \mathrm{mosm} / \mathrm{l}$, (=Median, Range 278-348). Adding HMF increased osmolarity up to $436 \mathrm{mosm} / \mathrm{l}$ (=Median; Range 386-486). Additional Protein+ supplementation increased osmolarity by $23.5 \mathrm{mosm} / 1$ (Median) per $0.5 \mathrm{~g}$ step, up to a maximum of $605 \mathrm{mosm} / 1(+4 \mathrm{~g})$. Osmolarity of $\mathrm{HM} /$ fortifier/Protein+ mixes remained stable for 24 hours. Multivitamin supplements increased osmolarity up to $842 \mathrm{mosm} / \mathrm{l}$.

Discussion Additional Protein+ increased osmolarity of HM up to a critical cut off point ( $>400 \mathrm{mosmol}$ ) and therefore might be a risk factor for developing NEC. Additional fortification of $\mathrm{HM}+\mathrm{HMF}$ with Protein + should not be applied together with multivitamins or other additives.

\section{NUTRITION OF THE EXTREMELY LOW BIRTH WEIGHT (ELBW) INFANTS: ARE WE MAKING A DIFFERENCE?}

doi:10.1136/archdischild-2012-302724.1399

R Snyder, S Allykas, A Mennonna, MR Rogido. Goryeb Hospital/MANA, Morristown, NJ, USA

Background Adequate nutrition of ELBW infants is difficult to achieve, yet crucial for their survival and neurodevelopment. Awareness of the problem and consistency in the care provided is a neccesary step for improving outcome.

Aim To evaluate the impact of recently instituted nutritional guidelines in ELBW in our NICU.

Methods Our NICU instituted nutritional guidelines in July 2008 after exhaustive review and discussion of best available evidence. Recommendations included early introduction of trophic enteral feeding (TF), timing and rate for advancing enteral feeds and criteria for its discontinuation, among others. We performed a retrospective review of charts in all ELBW admitted between January 2007 and December 2010. Demographic information, time to introduction of TF, age at which feedings were advanced and full feed were achieved, days on Total Parenteral Nutrition (TPN) and days of Percutaneously Inserted Central Catheters (PICC), growth parameters and outcome were analyzed and compared for ELBW population before (Period 1) and after (Period 2) the institution of nutritional guidelines.

Results

Abstract 1399 Table 1 Comparison between Period 1 and Period 2

\begin{tabular}{lll}
\hline & Period 1 (n=83) & Period 2 (n=103) \\
\hline TF at 48 hs (\%) & 37 & 39 \\
Enteral feeds > 20 ml/kg by DOL 7 (\%) & 42 & $60^{*}$ \\
Full feeds at DOL 28 (\%) & 41 & $80^{*}$ \\
Days on TPN (mean \pm SE) & $32 \pm 3.8$ & $22.7 \pm 2.4^{*}$ \\
PICC days (mean \pm SE) & $32.7 \pm 4.2$ & $21.4 \pm 2.5^{*}$ \\
NEC Stage 2 (\%) & 12.7 & 13 \\
\hline
\end{tabular}

${ }^{*} \mathrm{p} \leq 0.05 ; \# p \leq 0.02$

Conclusions The institution of nutritional guidelines resulted in significant improvement in nutritional indicators in our population.

\section{BODY FAT IN VLBW IS INFLUENCED BY DURATION OF TOTAL PARENTERAL NUTRITION (TPN)}

doi:10.1136/archdischild-2012-302724.1400

R Snyder, S McDonough, J Ladino, K Crowley. Pediatrics, Goryeb Childrens Hospital, Morristown, NJ, USA

Background Adequate postnatal nutrition and growth are essential for optimal neurodevelopment in VLBW infants. In an effort to optimize nutrition, early TPN implementation is recommended while enteral nutrition is achieved. However, excessive caloric intake could result in disproportionate accretion of body fat leading to metabolic syndrome later in life.

Aim To identify the influence of early postnatal nutrition on body fat composition in VLBW infants.

Design/methods We included all infants admitted to our NICU from July 30, 2011 to December 31, 2011 with a birth weight $\leq 1500$ grams that survived at least 4 weeks and received TPN. We excluded infants with major congenital anomalies. Body composition was measured weekly using an air displacement plethysmograph (PeaPod, CosMed). 